\title{
Eco Art \\ Bamboo and Silat Spirituality in the Integrated Space Design
}

\author{
Widya Poerwoko
}

Program Pascasarjana Institut Seni Indonesia Yogyakarta

E-mail: ruasbambu@yahoo.com

\begin{abstract}
Today environmental damage has become an alarming issue. Such a problem also occurs at Sleman located in the foot of Mount Merapi, Yogyakarta. Illegal sand mining around settlements has resulted in shrinking plant populations and damage to land use, which has resulted in decreased groundwater and surface water. Environmental damage begins with fragmentation in people's worldview resulting from the emerging humanism-ecology, knowledge-values, and the body-spirituality separations. Pencak silat, as an indigenous Indonesian martial art that is subject to the harmony between humans and the natural environment in which they live, can inspire the awareness of local people to reconsider the habits harmful to the environment and nature. The Integrated Space Design as an aesthetic manifestation of Eco-Art is an artwork created to address environmental problems occurring in the foothills of Mount Merapi by creating a space that bridges the interactions between humans, between humans and their artificial environment, and between humans and the surrounding natural environment by using bamboo plants as the main media, and silat spirituality as the primary inspiration the local community's capacity of living, both ecologically and spiritually.
\end{abstract}

Keywords: bamboo, silat, nature

\section{ABSTRAK}

Perubahan iklim dalam fenomena Global Warming penting diperhatikan. Meski peristiwa tersebut sulit dibayangkan oleh masyarakat pedesaan, namun faktanya fenomena tersebut telah mengakibatkan para petani mengalami kegagalan panen dan hampir tidak dapat lagi memprediksi waktu tanam. Di luar fenomena tersebut, persoalan lingkungan juga terjadi di kaki Gunung Merapi, Sleman, Yogyakarta. Penambangan pasir di pemukiman, telah mengakibatkan menyusutnya populasi tumbuhan dan rusaknya tata guna lahan, sehingga berdampak pada menurunnya permukaan air tanah dan air permukaan. Kerusakan lingkungan berawal dari terpecahnya cara pandang orang akibat dari munculnya pembedaan antara humanisme dengan ekologis, pengetahuan dengan nilai-nilai, dan tubuh dengan spiritualitas. Pencak silat, sebagai seni bela diri Indonesia yang tunduk pada keselarasan antara manusia dengan lingkungan alam tempat hidupnya, dapat menggugah kesadaran orang setempat untuk mempertimbangkan kembali kebiasaannya yang dapat merugikan lingkungan dan alam. Integrated Space Design sebagai manifestasi estetis Eco Art, merupakan karya seni yang diciptakan untuk menjawab persoalan lingkungan yang terjadi di kawasan kaki Gunung Merapi, yaitu dengan mewujudkan ruang, wadah atau 
jembatan interaksi antar manusia, manusia dengan lingkungan buatannya dan alam seputar hidupnya, dengan menggunakan tanaman bambu sebagai medium utamanya, dan spiritualitas silat sebagai inspirasinya sehingga dapat melestarikan daya hidup masyarakat setempat, baik secara ekologis maupun spiritual.

Kata Kunci: bambu, silat, alam

\section{INTRODUCTION}

\section{The Background of Eco Art Creation}

In 2002, the UN predicted that the lowland forests of Kalimantan and Sumatra, the main habitats for orangutans, would vanish by 2032. However, by 2007, researchers found that the rate of deforestation was actually occuring at a faster rate, which led to the conclusion that forests on both islands would be gone ten years earlier than previously thought. Massive looting of forests in upper watershed areas has resulted in ecosystem degradation downstream in rivers on which people depend for their livelihoods. This has threatened the sovereignty of community life as well as the intrinsic values contained in the greater river ecosystem.

According to Hariadi Kartodihardjo, a lecturer at the Faculty of Forestry, Bogor Agricultural Institute, though there is a need for rehabilitation programs for critical watersheds, the current rehabilitation programs are virtually meaningless in the face of current policies implemented by regional authorities as the policies are often counter-productive and even exploitative. Similar conditions exist along several rivers that flow through the city of Yogyakarta, namely the Winongo, Code, and Gajahwong Rivers. While these rivers all have a close relationship to the cultural dynamics of Yogyakarta and its people, all three watersheds are now subject to strong pressures from those who ignore the values of environmental sustainability. Unfortunately, environmental damage is not limited to urban areas only, and rural areas in the foothills of Mount Merapi have also experienced degradation due to illegal sand mining that negatively impacts land use, irrigation systems, and water catchments. The widespread nature of environmental degradation indicates that people's perspective, attitudes, and exploitative behavior towards natural resources no longer conform to a rural/urban boundary.

\section{Problem Formulation}

Eco Art is a unification of two words: Ecology and Art, or in Indonesian terminology, what is commonly referred to as seni berwawasan lingkungan (ecological arts). Eco Art seeks to bring back the coherence between the human value system and its view of nature. Eco Art is thus comprehensive because it 
must be so; it is a result of the awareness that people have no choice but to look at the world in a comprehensive, related, and global way. An integrated space design is an effort to regain self-awareness as well public awareness that all forms of art created by our ancestors and elders in the past are endless oceans of art to be understood, studied and then developed to benefit the local community. Traditional arts are real examples of integrated art, the result of the long processes of creations inseparable their from cultural and environmental contexts.

A key idea of Eco Art is to re-promote local knowledge as a foundation for understanding the importance of ecosystem sustainability. It is a response based on respect, love, and prudence exemplified by our ancestors to manage an environment that has been eroded or even almost destroyed. But to do this, we must ask what kind of creative concept can be built to realize an integrated design that accommodates a variety of interactions while at the same time revives the local community's awareness of their potentials, either in the form of skills or of various types of bamboo plants growing in their area?

Table 1. Basics of Landscape Philosophy

\begin{tabular}{cccc}
\hline No & Names & Symbols & Meanings \\
\hline 1 & Tao & 1 Origin \\
2 & Yin Yang & 2 Balance \\
3 & Sam Po & 3 Fusion \\
4 & Su Sie & 4 Directions \\
5 & Ngo Heng & 5 Elements \\
7 & Ciok Hap & 3 Fusions + 3 Utilizations \\
8 & Pat Kwa & 7 Colors/Senses \\
9 & Kiu Tao & 9 Pieces/Formulations \\
\hline
\end{tabular}

Source: Notes from the Dialogue of Suhu Subur Rahardja and WS. Rendra, 1973

Within the context of survival silat as a form of martial arts can be found an alternative for people to foster awareness of their potentials, in both ecological and spiritual terms. Silat is a science with which, through the body, people try to understand their existence of self in relation to nature. Through martial arts, people are trained to understand the interrelationships between mind, body, and spirituality, or which is also often referred to as mind, body and spirit, which in 
the Taoist concept is called Sam Po. Sam means three and Po means pearl, which means that an individual's actions or behaviors are the results of dynamic and complex interactions of the combinations of reflection, reaction, and action. Since silat is much influenced by and from its geographical source, namely Mainland China, Taoism is a relevant concept to uncover the spiritual aspects of martial arts. Taoism conceptualizes, nature as analogous to the human body, and the body is considered as a microcosmos, or what in Javanese philosophy is called jagad cilik. For the purpose here, this is called the Basics of Landscape Philosophy (The Tao of Silat), which consists of nine parts as depicted in Table 1.

The question then, is how to create an Integrated Space Design as a manifestation of Eco Art using bamboo plants as the main medium and martial arts spirituality as the inspiration, so as to restore the ability of local people to survive both ecologically and spiritually, and in the process reconsider those habits that are harmful to their environment.

\section{MATERIALS AND METHOD}

\section{The Basic Idea of Eco Art}

The basic idea of Eco Art is how to integrate bamboo and silat spirituality into an Integrated Space Design, as a manifestation of the Eco-Art aesthetic, to create a space of interactions between individual humans, between humans and their artificial environment, and between humans and the nature in which they live. This is to preserve the survival ability of local people both ecologically and spiritually. Silat spirituality serves as an inspiration in this context in that the space design has the quality of human life, a design that has the courage to recognize the spiritual and transcendental dimensions of humans.

The human body is a Tao, a part of the body of nature, "I am present and flowing (Tao), united in law with nature and subject to a dynamic balance (Yin Yang), with all the performance of my mind, body and spirituality (Sam Po), existent in space and time ( $\mathrm{Su} S \mathrm{Sie}$ ), in order to understand Thy signs, in deep silence, I process the five elements contained in my body (Ngo Heng). Now I am able to reformulate who I am (Liok Hap) and move continuously with Thy direction to greet my surroundings. In the desire to capture Thy divine values, I sharpen and refine the seven light waves of my senses (Jit Sek), with Thy permission and blessing I join in the web of life (Pat Kwa), now I surrender without doubt, if it is Thy will, whatever will be will be. Catastrophe and luck are just the same (Kiu Tao)." The aforementioned nine Taoist narratives are the order of art installations realized in the Eco Art Landscape. 


\section{The Idea of Form}

The form of space is associated with the relational sphere, namely relations between humans, human with the artificial environment, and human relations with immediate and present nature. The concept of integrated space design is developed in order to anticipate these three types of relations. In anticipating the problems that might arise, it is necessary to develop a new paradigm so that the design will be useful knowledge if it is no longer understood merely as an object of use, but as a system, a problem solving system. The public should be informed that the design output is not only in the form of physical objects as people have understood so far, but that it also takes the form of new activities and behavioral patterns in society.

The idea of artwork is realized in the form of a place of worship where the design accommodates different religions in the world as many people assume that interaction with the Creator only occurs in a place designated for it. The idea of a circular line as a symbol of dynamic cyclic movements is often depicted in the form of a sphere, so it makes sense if the roofs of worship places of various religions have a half-ball or dome shape. When you hear the word domelike roof, what comes to mind might be mosques, though in fact hundreds of years before Islam, Hindus, Buddhists, Christians and Catholics were familiar with dome shape and used it as part of their architecture.

\section{The Embodiment Method}

This section reviews the three stages and six steps in the process of embodying Integrative Space Design. It was inspired by the methods presented by Gustami in the book Proses Penciptaan Seni Kriya: UntaianMethodologi (Craft Artwork Creation Process: Methodological Strands), 2004. The three stages are a) the Exploration Stage, which in this context includes both Pengembaraan Jiwa (spiritual exploration) and theoretical basis development, b) the Planning Stage, which includes the steps of Designing and Model Making or Modeling, and c) the Embodiment Stage which includes the steps of creating the artwork and evaluating the results according to the purposes and the objectives of the artwork embodiment. Based on the three stages and the six steps, the embodiment method is further elaborated in keeping with the Integrated Space Design context.

a. The Exploration Stage

Pengembaraan Jiwa (spiritual exploration) as the first step in this context was a challenging phase in which the author was confronted with the reality of environmental damage in the foothills of Mount Merapi. Further examination was carried out through interviews and interactions with the local community in order to ascertain behaviors harmful to communitiy members and the environment in which they lived. The intense interaction between the author and the local community and their environment allowed for increased awareness and a deeper 
understanding of environmental damage in the target area. The author sought to broaden his own views by seeking out references from various disciplines' perspectives to answer the question of why environmental damage occurs after which the study problem was then identified and formulated.

b. The Planning Stage

Pre-designing was the third step in the process of transforming verbal descriptions of ideas based on the initial analysis into scaled sketches of basic forms of works within the two-dimensional design boundary. These sketches allowed for adjustments or modifications to the basc forms in accordance with the actual conditions in the field. Because this artwork used plants as its medium, this pre-designing process was necessary to allow a space for possible accommodations and changes both in terms of form and dimensions. The predesigning process also included the designing of zonal division as the art landscape was located in Surodadi hamlet was intended to be a part of the community life.

Designing, as the fourth step, was the process of selecting one of three alternative ideas or idea forms which was then translated into scaled engineering drawings along with the required detailed drawings. Since artwork design consists of two types of planning, namely landscape design and art installation work design, a site plan was also needed in order to map out where the installation artwork would be placed in accordance with the author's desired display narrative.

c. The Embodiment Stage

The process of embodiment as the completion step was carried out in the field and consisted of preparatory work including land clearing, measurement, and pegging. Once the 'shape sketches' of configuration were designated in the field, the next process was digging planting holes following the 'shape sketches'. This was followed by planting bamboo plants as planned at the site. After the bamboo was established, the plants were arranged and maintained as needed, in order to direct and control the shape and growth of the bamboo plants, and avoid deformation and a resulting decrease in the artwork's function. This work resembled the process of making a model in that if a model is made with a 1:50 scale, for example, then the actual work uses a 1:1 scale.

Gustami further explains that, for artworks with a practical function, the evaluation should be based on both functional and analytical criteria, and include the possibility of developing an exhibition in order to obtain responses from the user community. The evaluation is meant to criticize the quality of a work that involves both physical and non-physical aspects, including personal, social, and cultural functions. Once the functional work criteria have been met, the work is ready to be produced and then released to the public. However, since the Integrated Space Design is an ecological artwork, that is, an artwork that aims to 
answer the problem of environmental damage in an area, then this artwork cannot be duplicated without considering the ecological and environmental aspects, including the socio-cultural aspects of the local community.

\section{RESULTS}

Nature, including human nature, is an organism, and an organism is an orderly system of anarchy. Even though there is no 'boss' in it, nature can keep going in harmony even if it is permitted to run just the way it is. This is what is called Tao, or Jagad (the universe) in Javanese language which is then developed into Nggelar Nggulung Ngelar Jagad, which consists of nine steps. These steps imply studying, understanding, and developing the potential of the human body according to its nature. However, instead of reflecting harmony, the form of the work as a whole reflects the disharmony of Jagad (the universe) as a result of the schism in people's reactions to degradation and separation occurring in almost all aspects of life. The nine works realized in the area of Art Landscape were visualizations of the basic philosophy of the lanscape. It is a portrayal, depiction, embodiment, or representation of the spirituality of the human body, including Tao, Im Yang, Sam Po, Su Sie, Ngo Heng, Liok Hap, Jit Sek, Pat Kwa and Kiu Tao.

The title of the first installation work was Tao (see Figure 1), the shape of which resembles the dome of a Sanchi stupa, a half-spherical place of worship made of bricks found in Buddhist sites. This first Tao is akin to the body of a new born, who is innocent, honest, and pure. Because the brain is not yet 'active' in responding to various events, the body with all of its instruments naturally receives stimuli from its surroundings. Therefore, the title of this particular Tao's artwork became 'reBorn.' To make it more digestible to the local community, the title was changed to 'Orok,' which is another name for 'Jabang Bayi' (newborn baby), the developmental period of which, according to psychologists, is the shortest in the human life span.

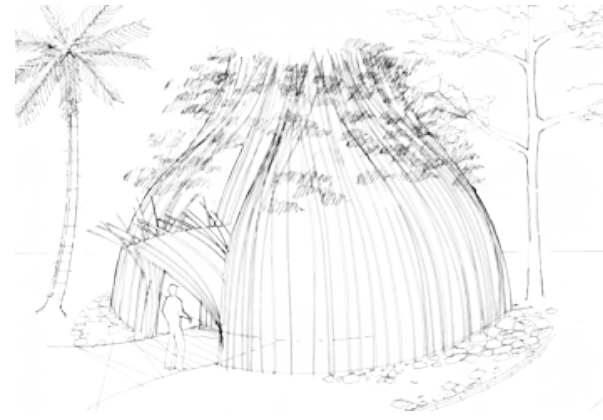

Figure 1. The Perspective of Tao/Orok

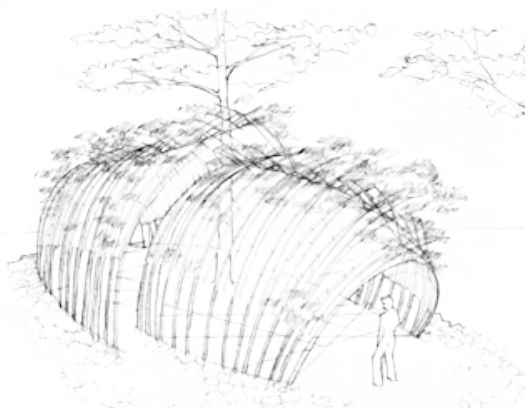

Figure 2. The Perspective of Im Yang/Sigar Penggalih 
The second work was called Im-Yang (see Figure 2), the shape of which resembles the roof of the Pohsarang Church building in Kediri, which looks like an upside down boat split or divided into two parts. This work functions as a performance room with a capacity for an audience of 50 people. Im-Yang is a pair of realities that inevitably have to be accepted as part of life. Therefore the title the Im-Yang's art creation was changed into 'Split Off', meaning that people are trapped in a dichotomy of dualism of the mind that is spirituality alienated from the body. However, like the local naming of a specific plant, this work was given a name that would resonate better with the local community, 'Sigar Penggalih', a Javanese phrase which means the splitting of a single view between the mind and human spirituality.

Figure 3 shows the third work entitled Sam Po, the shape of which resembles a Pagoda tower. In the artwork context, Sam Po describes the human body which is a fusion of three elements: mind, body, and spirituality, which gives arise to human consciousness. In the context of silat, the tower is a symbol of gallantry, a unified body structure that is upright, strong and sturdy, but the deterioration in the tower's function inspired the naming of this particular Sam Po artwork as 'Drunken Tower'. It is a tower that is drunk and/or losing some of its consciousness, which in the local language is called 'mendem'. The term 'mendem' implies several meanings, among which is excessive euphoria or 'mabuk kepayang' which in local terms is commonly referred to as 'mendem kahanan', being drunk while still conscious. Another meaning of the word "mendem" is loss of consciousness, forgetfulness, infatuation or excessive lust, and therefore the title "Drunken Tower" was transformed into the local term "Mendem Kahanan."

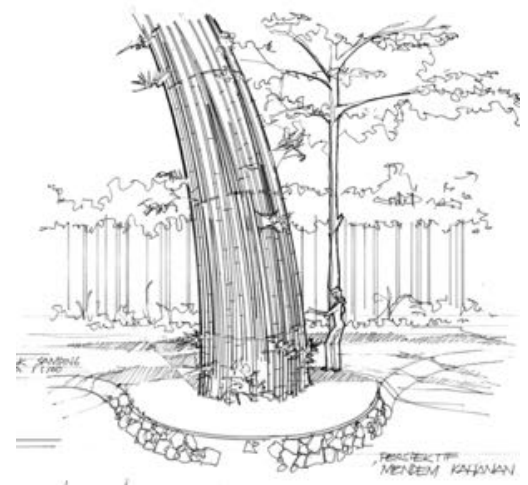

Figure 3. The Perspective of Sam Po/Mendem Kahanan

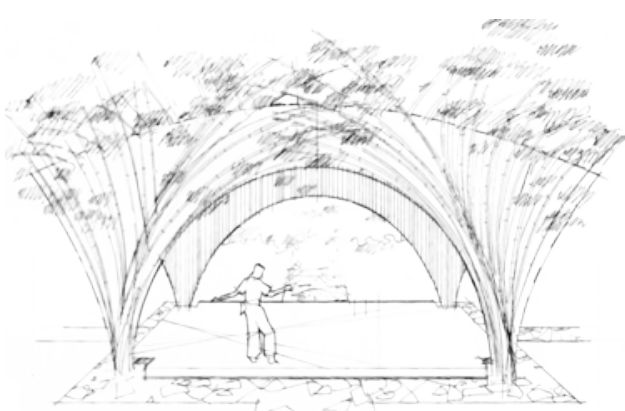

Figure 4. The Perspective of $S u$ Sie/Suwung 
Figure 4 shows the fourth work entitled Su Sie the shape of which resembles the dome of the Sakirin Mosque in Istanbul, Turkey. This space serves as the connector to other spaces around it. This particular work relates functionally to the first work. While Tao/reBorn/Orok serves as a performance room, Su Sie serves as a mediation space, a space for dialogues between audience and artists, and musicians. In the context of art creation, $\mathrm{Su}$ Sie is described as four directions, or four angles, and correlates to the position of man on Earth. With these orientations, being in space and time, life both influences and is influenced by the environment. In the reality of life, every individual should accept that he/she has a body, a mind, feelings, and desires. However, orientation, space and time are never wrong. It is humans that sometimes misplace themselves or lose their direction. Therefore, the title of $\mathrm{Su}$ Sie artwork was changed to 'off Side'. In Javanese terms, this particular work was named 'Suwung', a nickname given to a dazed individual who is jobless, is daydreaming, and confused from a lack of orientations and purpose.

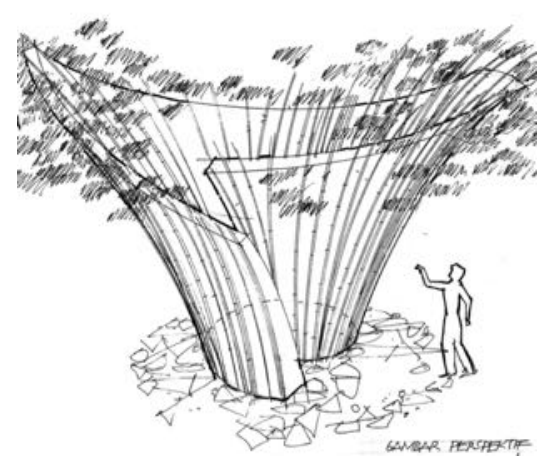

Figure 5. The Perspective of $\mathrm{NgO}$ Heng/Mo Limo

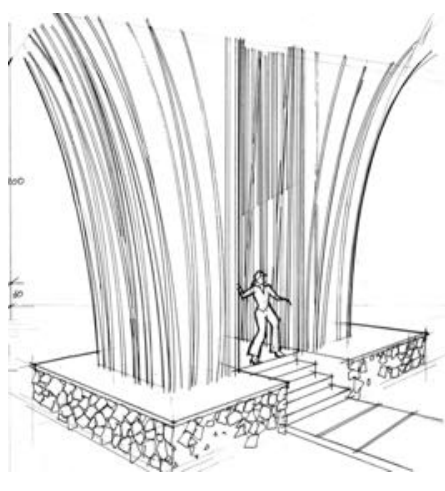

Figure 6. The Perspective of Liok Hap/Lawang Awangen

Figure 5 shows Ngo Heng, the fifth artwork, the shape of which resembles a hollow stupa with a Buddha statue similar to the large stupas of Borobudur Temple. In the context of this artwork, the stupa was turned upside down, making it conical upwards instead of downwards. Ngo Heng in the context of silat is a metabolic process of five elements or five main organs of the human body involved in the digestive process of food resulting from plant photosynthesis. The meaning to be conveyed by this particular work was that even when perfect metabolism produces 'vital energy', commonly referred to as $C h i$, if not properly 
guided to access thepoint of human spiritual consciousness, the 'vital energy' will not go anywhere but to the genitalia. Therefore the title of Ngo Heng art creation was transformed into 'Suffering Return'. This particular work was meant to represent the return of human suffering as a result of an inability to control the 5 (five) zests inherent in the body, which in Javanese philosophy is called molimo. The origin of the term molimo is Moh (do not want) Limo (five), or not wanting to engage in the five misconducts, including mendem (drinking), main (gambling), madon (promiscuous sexual behavior), madat (drug addiction), and maling (stealing). Therefore, the title of this particular work was transformed into 'Mo Limo'.

Figure 6 shows the sixth artwork named Liok Hap which consists of 'three fusions' and 'three uses', the phase where an individual must start moving all of his/her body elements to interact personally and stay in touch with all forms in the web of life. Liok Hap is a gate that resembles an archeological artifact of the Majapahit kingdom called the Wringin Lawang gate in Mojokerto. In the context of art creation, while gapura (gate) is commonly interpreted as the getway to an area, or the entrance gate to royal complex, the Liok Hap piece is the gateway to the idea of starting a new chapter in life, to read reality, capture information, and 'digest' these so as to become knowledgable enough to change one's behavior. Liok Hap is the process of transforming the mind into implementation, but because the gate of the mind sometimes stands too 'gloriously', it is too often that an idea is pondered and embodied but not successfully implemented. Therefore Liok Hap was then named 'Mind Gate', which in local terms was translated as 'Lawang Awangen', a combination of two Javanese words lawang which means door and awang-awangen which means refrain from doing something because of reluctance, doubt, or fear of failure.

\section{DISCUSSION}

Nggelar Nggulung Ngelar Jagad in this context aligns itself with nature in an effort to solve the problem of ecological balance in order to engage the sensitivity of organisms in the web of life as more 'we' than 'me' in nature. Nature, including the human realm, is an organism, and an organism is an orderly system of anarchy. Nature can keep going in harmony even if it is allowed to run its course. Art Landscape is an ecological artwork which contains three aspects, namely (1) the aspect of function, which is judged based on its ability to accommodate human body activities to understand relations between humans, (2) the aspect of role, which is judged based on its abilities to build relationships between humans and their artificial environment, and (3) the aspect of meaning, which is judged by its 
ability to interpret the relationship between humans and the surrounding natural environment.

\section{The Function Aspect of Space}

The Art Landscape is a place or space for the interactions and activities of various groups of people or communities, including silat, art, peasants, bamboo, and surrounding communities. In addition, the Art Landscape has often been used by students from various Higher Education Institutions to carry out training, discussions, and/or just sharing. Art and cultural communities such as Sawung Jabo Music group with its Barock Circus, Teater Dinasti, Teater Garasi, Teater Gajah Mada, and Omah Panggung Nitiprayan, either in groups or individually have used the space to practice music or even theater, perform general rehearsals before an actual performance, or carry out discussion activities, program evaluations, retreats or informal gathering. The local community group uses it as a regular practice site for the Macapatan and Cokekan traditions.

\section{The Role Aspect of Space}

The existence of the bamboo plants has perhaps been the strongest reason why most of the Art Landscape users choose this site as an interaction space, especially when people know, albiet in a limited fashion, that Eco Art is gradually showing its intended shape. Some people begin to be feel 'intrigued' with the atmosphere of the space and feel provoked to comment on the Nggelar Nggulung Ngelar Jagad' artwork. One question that is often asked by many people is why bamboo plants have been used and what is the connection with silat spirituality. Another frequent question is about the use of this space during the rainy season.

Questions arising from cultural circles include what the Art Landscape is used for, and to the extent of its usefulness to the local community. Another interesting question from the local community is whether they can take the grass growing in the Landscape Art to feed their livestock. In general people assume that the artwork is not beneficial to them because aside from bending bamboo plants, the bamboo species used to make the artwork does not sell well in the market, so it does not provide direct economic benefit to the community.

\section{The Meaning Aspect of Space}

The most prominent human interaction with nature that came to life was apparent when the bamboo plants formed into artworks and spaces, 'luxuries' that cannot be found elsewhere. Watching bamboo plants grow into a living building that continually refines its shape is a show in itself. Nggelar Nggulung Ngelar Jagad is a synthesis of bamboo plants and silat spirituality. It is the aesthetic manifestation of Eco Art that makes bamboo plants not only serve as the material to realize the artwork, but also as the medium, or the delegation of nature that requires study, understanding, and comprehension as the web of life. Silat spirituality acts as a microscope on the one hand, and a telescope on the other, 
both of which can be used to understand the web of life and the interconnectedness of cosmos. In the end, the space continues to serve as a bridge that reconnects humans, humans with their artificial environment, and humans with nature.

Integrated Space Design is not a design method intended for people who just want to enjoy short-term benefits, who cannot take into account their own survival and that of the generations to come, nor is it for people who only want to multiply capital. This is because the designing in this context is not merely building a building, rather, it is designing a space to awaken people from their long 'unconscious state.' Given the many kinds of disintegrating influences in the reality of human life (that itself damages the essential elements of life), Integrated Space Design integrates what has been scattered by quantifications of science, knowledge and human life. Space in the context of Eco Art is a vessel, a bridge of interaction, and a point where logos and praxis meet and interact to improve the quality of life.

\section{CONCLUSION}

The general conclusion of Integrated Space Design as an aesthetic manifestation of Eco Art is that it succeeded in presenting Nggelar Nggulung Ngelar Jagadthemed artwork with accompanying installation works growing in it, using bamboo plants as the main medium, and silat spirituality as the inspiration. In accordance with the purpose and objectives, the art landscape is created to carry out its role as a space, a vessel or a bridge of interactions between humans, between humans and their artificial environment, and between humans and nature around their lives. Today the presence of the art landscape in the region is starting to receive positive responses from the local community. This is indicated by the emerging collective idea to restore the function of the land formerly used for sand mining in accordance with its designation. This is where Integrated Space Design can serve as an alternative solution to transform critically damaged land into conservation land. Therefore, illegal mining must be stopped, which also means stopping other activities that can harm the environment to prevent additional losses and damage in the future. If illegal mining is not stopped, at least gradually, then the program is merely digging a hole to close another one in the real sense, which in the end will leave a debt to be paid by future generations.

From the function aspect, Integrated Space Design has proven to be capable of accommodating inter-human interactions as during activities with several silat, art, bamboo, and environmentalist communities held events in the forms of group exercise, informal gathering, workshops, discussions, refearsals for performances, or recreational activities. This was in addition to students from 
various higher education institutions which held similar activities in the Art Landscape. Meanwhile, young people from the local community together with students from the Faculty of Psychology, Yogyakarta State University often used this space as a place for practicing outbound activities and children's games or what are commonly called Dolanan anak by local community.

From the role aspect, Integrated Space Design has shown its ability to accommodate human interaction with the artificial environment when journalists, cultural observers, education and environment activists, both from local, national and international levels positively appreciated the living, organic space and artwork that uses bamboo plants, which themselves have significant meaning as a medium. Bamboo plants, which have historically been considered as gendruwo (ghost nests) by the local community and also known to be used as hiding places for criminal gangs are now gradually gaining respect and even being treated as a glorified plant. In addition, the landscaping with the composition of building structures and the installation artwork growing on it serves to control erosion, create a nutrient blanket for the soil and as protection for the water catchment area.

In terms of meaning, Integrated Space Design has become a bridge for interactions between humans and the surrounding natural environement where artists, cultural observers, and international martial art communities appear to be so closely connected with the web of nature. They patiently wonder what aspects of the work will be shared with the local community. They are also concerned about people's impact on nature, and feel that bamboo works as a medium or 'antenna' to in bringing them together in the same space and time. Nggelar Nggulung Ngelar Jagad is a narrative of silat spirituality, driven into implementation, becoming a tangible and spatial narrative in the form of an integrated space design. It is born, grows and then unites with community life, culture and surrounding nature.

Another important aspect that supportsthe embodiment of Integrated Space Design as an aesthetic manifestation of Eco Art, is if the artworks using bamboo plants as the main medium and silat spirituality as the source of inspiration are studied and consequently developed into a dissertation subject. Such opportunity would allow people to learn how to 'refine' their spiritual experiences when greeting and 'dialogueing' with other living things called 'plants', because they grow around us. We even inhale the oxygen they produce and consume them to provide our bodies with important energy and nutrient as a necessary ingredient of spirituality itself.

Another supporting factor is the potential to reintegrate the specialized art science into Eco Art, so that students do not have to depart either from a box called applied art or pure art for it would be like separating interrelated knowledge 
from one another. For instance, separating Im and Yang, separating men from women, separating the right brain from the left, separating theory from practice, separating ideology from art, which at the end will separate quantity and quality of life are all perspectives that contribute to environmental damage throughout the world. It is in the context of Eco Art creation where the author has the opportunity to reconcile one with the another, to integrate dualism in the human body which often causes symptoms of 'schizophrenia' to appear in the various elements of life.

There were technical factors that both supported and inhibited the project that arose from the use of bamboo as the artwork media. The use of bamboo requires a longer time for the embodiment of the work to be complete, however, the extended length of time was also beneficial, and therefore became a supportive factor because it provided the author more time to record changes in the plants from various perspectives. These changes were both qualitative and quantitative, for instance, with the Su-Sie piece, which originally was called "off Side", and then integrated into Suwung, and demonstrated that space is indeed inseperable from time.

Ecological art education can be an alternative to improve the ability of the local community's ability to read, absorb, and understand the information displayed by bamboo plants regardless of their species and family, then mimic the patterns and the ways the bamboo plants preserve themselves. Such activities are useful to foster new awareness considering that many people only understand the price but do not realize the value, understand the profit but do not realize the benefits, so that it becomes important to integrate ecoliteration-ecodesign into the lives of local communities in the Surodadi Hamlet area. Ecoliteracy and ecodesign have been developed in universities in various developed countries with purpose of changing the way people think so that they will be willing to imitate the manner in which the web of life survives. Taking waste from one organism to become the raw material for the lives of another organism is an example. We should not see rubbish as waste that must be disposed of, but as raw material for creating new products. This method was exemplified by our predecessors in traditional farming techniques where plants were cultivated to allow for alternate harvesting according to the season with some of the produce consumed, some stored for seed reserves, and some to feed livestock which in turn produce soil fertilizers. It was a cycle that enabled a pattern called the web of life. In the context of Integrated Space Design, individuals, communities, or institutions that come to the site are seen as parts of a web of life that provide input for the survival of the Art Landscape area, be it energy, material, information or knowledge. Therefore, an alternative perspective where improving the quality of life allows people to see a more complete picture of the interconnectedness of the web of creation. 
It is recommended to people who plan to use plants as a medium to create something to equip themselves with adequate knowledge of the plants they intend to use, where they grow and what role the plants play in the cultural life of the local community. Such knowledge is derived from long experience with a plant where knowledge of it has been passed down through the generations.

The planting media and the plants must be prepared in advance. Through these preparatory steps, people will better understand the soil or the planting media needed as nutrition for the plants are required to realize the work. Alternatively, the plants also provide information and can impart knowledge to the artists so that they understand the type of planting media needed by the plants to grow as hoped. In this way, the artists will be able to calculate the speed of growth of the plants against the time available to complete their studies. Because the work will always be related to human life, it is necessary to work together with people from other disciplines, as partners or counterparts to help the artists obtain information and knowledge related to soil elements such as microorganisms and other knowledge related to habitats where a type of plant typically lives and develops.

The Ecological Art Landscape in Surodadi Hamlet area began to demonstrate success when some of local people responded positively to its existence and subsequently invited the author to join in designing and realizing works similar or related to Eco Art at the former location of sand mining. Their goal was to establish a creative, recreational and educational space for the community, including both local people and the wider society. Now the Art Landscape has been accepted by local people as part of the web of life and has the opportunity to contribute by creating new spaces with improved life quality.

\section{REFERENCES}

Alexandersson, Olof. 1995. Living Water: Victor Schauberger and the Secrets of Natural Energy. UK: Gateway Books, Bath.

Barlow, Maude dan Tony Clarke. 2002. Blue Gold: The Battle Against Corporate Theft of the World's Water atau Blue Gold: Perampasan dan Komersialisasi Sumber Daya Air, terjemahan Nila Ardhani 2005. Jakarta: Gramedia Pustaka.

Djoko Sujarto. 2005. Kota Berkelanjutan. Bandung: Penerbit Alumni.

Capra, Fritjof. 1999. Menyatu dengan Semesta: Menyingkap Batas antara Sains dan Spiritualitas. Yogyakarta: Fajar Pustaka Baru.

Capra, Fritjof. 1999. The Tao of Physics: An Exploration of the Parralels between Modern Physics and Easter Mysticism atau Menyingkap Paralelisme 
Fisika Modern dan Mistisisme Timur, terjemahan Aufiya Ilhamal Hafizh, 2000. Yogyakarta: Penerbit Jalasutra.

Capra, Fritjof. 2002. The Hidden Connections, atau Strategi Sistemik Melawan Kapitalisme Baru, terjemahan Andya Primanda, 2004. Yogyakarta: Jalasutra.

Chia, Mantak dan Maneewan Chia. 1995. Living in The Tao atau Hidup dalam Naungan Tao, terjemahan T. Zaini Dahlan, 1998. Jakarta: Pustaka Delapratasa.

Ching, D.K. 1979. Architecture: Form, Space and Order atau Arsitektur: Bentuk, Ruang dan Susunannya, terjemahan Paulus Hananto Adjie, 1984. Jakarta: Erlangga.

Ching Ni, Hua. (--). The Power of Natural Healing atau Kekuatan Penyembuhan Natural, terjemahan Oentung Yuwono, 1997. Jakarta: Pustaka Delapratasa.

Ching Ni, Hua. 1979. Tao: The Subtle Universal Law and The Integral Way of Live atau Pedoman Hidup Selaras dengan Tao, terjemahan Oentung Yuwono, 1997. Jakarta: Pustaka Delapratasa.

Coats, Callum. 1996. Living Energies: An Exposition of Concepts Related to the Theories of Viktor Schaubager, 1998. UK: Gateway Books, Bath.

Collingwood, R.G. 1974. The Principle of Art. New York: Oxford University Press.

Conrad, Jillian. 1997. Eco-Villages and Sustainable Communities: Models for $21^{\text {st }}$ Century Living. Scotland: Findhorn Press, Forres.

Daldjoeni, N. dan A. Suyitno. 2004. Pedesaan, Lingkungan, dan Pembangunan. Bandung: Alumni.

Frick, Heinz. 1996. Arsitektur dan Lingkungan. Yogyakarta: Soegijopranata University Press, Kanisius.

Gie, The Liang. 2004. Filsafat Keindahan. Yogyakarta: Pusat Belajar Ilmu Berguna (PUBIB).

Gie, The Liang. 2004. Filsafat Seni, Sebuah Pengantar. Yogyakarta: Pusat Belajar Ilmu Berguna.

Gorz, Andre. 1975. Ecologie et Politique atau Ecology as Politics atau Ekologi dan Krisis Kapitalisme, terjemahan Komunitas Apiru/Yogyakarta, 2002. Yogyakarta: Insist Press.

Gustami, S. P. 2000. Seni Kerajinan Mebel Ukir Jepara: Kajian Estetik Melalui Pendekatan Multidisiplin. Kanisius: Yogyakarta.

Gustami, S. P. 2004. Proses Penciptaan Seni Kriya, Untaian Metodologis. Yogyakarta: Program Pascasarjana S2 Penciptaan dan Pengkajian Seni ISI. 
Hunter, Beatrice Trum, dan Thomas Hirsch. 2004. Air and Your Health atau Udara dan Kesehatan Anda, terjemahan Brahm Udumbara P., 2006. Jakarta: Bhuana Ilmu Populer.

Ibrahim, Idi Subandi. 2004. Dari Nalar Keterasingan Menuju Nalar Pencerahan: Ruang Publik dan Komunikasi dalam Pandangan Soedjatmiko. Yogyakarta: Penerbit Jalasutra.

Kartika, Dharsono Sony. 2004. Seni Rupa Modern. Bandung: Rekayasa Sains.

Kartika, Dharsono Sony. 2004. Pengantar Estetika. Bandung: Rekayasa Estetika.

Keraf, A. Sonny. 2006. Etika Lingkungan. Jakarta: Penerbit Buku Kompas.

Kodoatie, Robert J. dan Roestam Sjarief. 2005. Pengelolaan Sumber Daya Air Terpadu. Yogyakarta: Andi.

Koentjaraningrat. 2002. Kebudayaan, Mentalitas, dan Pembangunan. Jakarta: Gramedia.

Korten, David C. 1999. The Post-Corporate World atau Kehidupan Setelah Kapitalisme, terjemahan A. Rahman Zainuddin, 2002. Jakarta: Yayasan Obor Indonesia.

Lawson, Bryan. 1980. How Designer Thinks, The Architectural Ltd. atau Bagaimana Cara Berpikir Desainer, terjemahan Harfiyah Widiawati, 2007. Yogyakarta: Penerbit Jalasutra.

Maliszewski, Michael. 1998. Spiritual Dimensions of the Martial Arts. Rutland: Charles E. Tuttle Company.

Mangunwijaya, Y.B. 1992. Wastu-Citra: Pengantar ke Ilmu Budaya Bentuk Arsitektural, Sendi-Sendi Filsafatnya Beserta Contoh-Contoh Praktis. Jakarta: Gramedia.

Marianto, M. Dwi. 2002. Seni Kritik Seni. Yogyakarta: Lembaga Penelitian ISI Yogyakarta.

Marianto, M. Dwi. 2004. Teori Quantum, untuk Mengkaji Fenomena Seni. Yogyakarta: Lembaga Penelitian ISI Yogyakarta.

Marianto, M. Dwi. 2006. Quantum Seni. Semarang: Dahara Prize.

Mitchell, Bruce, B. Setiawan dan Dwita Hadi R. 2003. Pengelolaan Sumberdaya dan Lingkungan. Yogyakarta: Gadjah Mada University Press.

Read, Herbert. 1959. The Meaning of Art atau Seni: Arti dan Problematikanya. Tejemahan, Soedarso Sp., 2000. Yogyakarta: Duta Wacana University Press.

Sachari, Agus. 1986. Paradigma Desain Indonesia. Jakarta: Rajawali.

Sachari, Agus. 2005. Pengantar Metodologi Penelitian Budaya Rupa: Desain. Arsitektur, Seni Rupa, dan Kriya. Jakarta: Erlangga. 
Sachari, Agus. 2002. Estetika: Makna, Simbol, dan Daya. Bandung: Penerbit ITB.

Samekto, F.X. Adji. 2005. Kapitalisme, Modernisasi, dan Kerusakan Lingkungan. Yogyakarta: Pustaka Pelajar.

Sastrapradja, Setijati, Elizabeth A. Wijaya, Soehardjono Prawiroatmodjo, Soejatmi Soenarko. 1977. Beberapa Jenis Bambu. Bogor: Lembaga Biologi Nasional-LIPI.

Setiono, Kusdwiratri, Johan S. Mansjhur dan Anna Alisyahbana. 1998. Manusia, Kesehatan dan Lingkungan, Kualitas Hidup dalam Perspektif Perubahan Lingkungan Global. Bandung: Penerbit Alumni.

Shiva, Vandana. 2002. Water Wars: Privatization, Pollution, and Profit atau Privatisasi, Profit, dan Polusi, terjemahan Achmad Uzair, 2003. Yogyakarta: Insist Press dan Walhi.

Siahaan, Bastian. 1999. Diversitas, Pelestarian Jenis, Pengolahan dan Pemanfaatan Bambu di Yayasan Bambu Lingkungan Lestari, Ubud, Bali (Laporan Praktek Kerja Lapangan). Fakultas Biologi Minat Studi Pengelolaan Lingkungan Universitas Kristen Duta Wacana, Yogyakarta.

Simpson, G.M. 1990. Seed Dormancy in Grasses. New York: Cambridge University Press.

Skolimowski. Henryk. 1981. Eco-Philosophy: Designing New Tactics for Living atau Filsafat Lingkungan: Merancang Taktik Baru untuk Menjalani Kehidupan, terjemahan Saut Pasaribu, 2004. Yogyakarta: Bentang Budaya.

Soedarso, Sp. 2000. Sejarah Perkembangan Seni Rupa Modern. Jakarta: Studio Delapan Puluh.

Soedjono \& H. Hartanto. 1991. Budidaya Bambu. Semarang: Dahara Prize.

Soemarwoto, Otto. 2001. Ekologi Lingkungan Hidup dan Pembangunan. Jakarta: Djambatan.

Sony, Kartika Dharsono. 2004. Pengantar Estetika. Bandung: Rekayasa Sains.

Sumardjo, Jakob. 2000. Filsafat Seni. Bandung: Penerbit ITB.

Takwin, Bagus. 2001. Filsafat Timur: Sebuah Pengantar ke Pemikiran-Pemikiran Timur. Yogyakarta: Jalasutra.

Wardhana, Wisnu Arya. 2004. Dampak Pencemaran Lingkungan. Yogyakarta: Andi.

Watts, Alan. 1995. The Tao of Philosophy atau Tao Filsafat, terjemahan Saut Pasaribu, 2003. Yogyakarta: Jendela. 